Relations industrielles

Industrial Relations

\title{
B.C. ROBERTS : Industrial Relations in Europe. The Imperatives of Change. Dover, New Hampshire, Crown Holm, 1985, 277 pp.
}

\section{Solomon Barkin}

Volume 41, numéro 2, 1986

URI : https://id.erudit.org/iderudit/050214ar

DOI : https://doi.org/10.7202/050214ar

Aller au sommaire du numéro

Éditeur(s)

Département des relations industrielles de l'Université Laval

ISSN

0034-379X (imprimé)

1703-8138 (numérique)

Découvrir la revue

Citer ce compte rendu

Barkin, S. (1986). Compte rendu de [B.C. ROBERTS : Industrial Relations in Europe. The Imperatives of Change. Dover, New Hampshire, Crown Holm, 1985, 277 pp.] Relations industrielles / Industrial Relations, 41(2), 417-422.

https://doi.org/10.7202/050214ar

Tous droits réservés (C) Département des relations industrielles de l'Université Laval, 1986
Ce document est protégé par la loi sur le droit d'auteur. L'utilisation des services d'Érudit (y compris la reproduction) est assujettie à sa politique d'utilisation que vous pouvez consulter en ligne.

https://apropos.erudit.org/fr/usagers/politique-dutilisation/ 


\section{RECENSIONS \\ BOOK REVIEWS}

Industrial Relations in Europe. The Imperatives of Change, by B.C. Roberts, Dover, New Hampshire, Crown Holm, 1985, 277 pp.

Affable teams of Swedish employers and unionists are not now as likely to visit other national and international bodies to describe and celebrate their successes in achieving mutual understanding and maintaining an effective and efficient industrial relations system. In view of the vast changes in the field, outsiders are not apt to consider this experience as a model for their countries. Criticism of the system emanates from both employers and employees, but particularly among employers. A major target is unions' use of parliamentary action to achieve their new goals, when meeting stiff resistance in negotiations. Under the current system, Swedish unions and employees may now, by reason of law, question corporate decisions and innovations respecting production and business operations, personnel rules and practices, work assignments and conditions and investments of excess profits. In response to these developments, employers also coopted political action to combat these and other changes. They began a public relations campaign to support their positions. The intensity of these efforts reached a high mark in 1983 , when the industrialists and their supporters took to street demonstrations in Stockholm to protest the establishment of employee investment funds.

The Swedish Employers Federation (SAF) program sought to restore past patterns for resolving differences between management and unions through discussions between the central organizations, SAF and the Swedish Federation of Labor (LO), without resort to the political system. The SAF also urged the LO to scrap its legislative proposals for challenging management's unilateral rights to operate its enterprises. Economic demands should be moderated to enable management to maintain financially sound and competitive enterprises. Excess profits should not be taxed away for allocation to employee investment funds. Actual bargaining should be decentralized to the sector and plant levels.

To win broad support for its views, the SAF sponsored a study of industrial relations in eight European countries and the European Community and a statement by an American employer on the European systems. The responsibility for this project was assigned to a group of Swedish industrialists and directors of employers' associations who invited ten persons to prepare their evaluations. The authors, nationals of the countries about which they wrote, are economists, journalists, but principally management consultants, rather than participants in the collective bargaining system. The major exception is the contributor on European trends, formerly an official of the European Economic Community. The original Swedish report published in 1985 evoked an «intense debate». The English version was edited by B.C. Roberts, Professor Emeritus of the London School of Economics and Editor of the British Journal of Industrial Relations. He also contributed a chapter on Great Britain and «A Summary Conclusion».

\section{Overall Evaluation}

The contributors had a common reference memorandum provided by the project group, which presumably focused on the central current Swedish issues as seen by the SAF and called 
for long term forecasts of the state of industrial relations in the respective countries. Though the writers are not directly affiliated with employers' associations, their chapters reflect employer concerns, outlook and values. They have little empathy for the humanistic aspirations prevalent on the continent during the sixties and seventies. These they tend to characterize as radical and even disruptive of the existing economic and social system. Where these views emerge in trade union thinking, they are labeled as alien and incongruent with the maintenance of a stable society. None of the contributors make any effort to evaluate the merits of the proposals themselves. Practically all call for the restoration of the postulates of the earlier postwar era of industrial relations.

Minimal are the references to plant personnel practices which address the new expectations among employees. The Danish author notes that the relaxation of the union drive for change led employer associations to drop their interest and study of alternative remedies. Though not explicitly stated, the writers appear to welcome a state of relations in which management would be able freely to meet the test of a competitive market in terms of financial results with a minimum of distraction from employee disturbances and dissent. The American contributor besides noting that some American employers have vigorously sought what is enthusiastically called a «union-free environment» have in some instances «succeeded beyond their wildest dreams». He omits all reference to union representation itself in his guidelines for European industrial relations. They object to worker and union participation in the management process as likely to «awaken class tensions».

The partisan nature of the presentation is further underscored by its stress on the so-called radical nature of union proposals. Moreover they fail to take cognizance of the predominating moderate views in all branches of the labor movement. Even in Great Britain, little is said about the significant trend toward the election of moderate union leaders and the determination of the Labour Party to rid itself of Marxists of the Militant Tendency group. Denmark and France exhibit the same direction, adding to the overwhelming numbers of likeminded leaders in the front ranks of the movement in other countries.

The book makes clear that employers and their organizations view the recession, the consequent increase in unemployment and the swing to the political right as an opportunity to stiffen their resistance to union demands. But little is reported on the unwillingness of most conservative governments to join in this foray. The Swedish non-socialist governments sponsored no regressive measures against unions. Most governments concentrated on moderating wage and benefit increases rather than on an outright battle with unions. Actually, unions in this period secured critical gains in their rights and status in a number of European countries, particularly those with Socialist governments. Without offsetting the malaise created by the economic setbacks the continental union movement achieved a more secure footing.

The claims of shrinkage are not supported by the careful analysis ${ }^{1}$. The actual experience has been uneven, with some national movements reporting impressive or moderate gains, others, little change, and still others, considerable losses. Individual chapters report an impressive expansion of membership in nontraditional areas, particularly women and white collar, professional and public service employees. One of the ironies in these reports is that in describing the internal tensions generated by the rise of the new parallel federations and independent unions among these new classes of membership, they fail to realize that this new group of supporters, even among the most professional and highest paid employees in both the private and public sectors, add immediate strength to the unions' role in the industrial relations

1 The most recent effort at compiling and evaluating the membership information is to be found in Kenneth Walsh Trade Union Membership Methods and measurement in the European Community. Office for Official Publications of the European Community, Luxembourg, $1985,118 \mathrm{pp}$. 
systems. The authors tend to focus on the cases of friction among organizations and bypass the many efforts at coordination and occasions of joint statements and action. In some countries mergers have been effected and, in others, have been discussed.

The writers tend to overlook the contributions which governmentally prescribed, and, of course union sponsored, works councils have made to strengthening the movement assuring a more articulated chain of communication for workers from the local level to the top union agencies. No analysis is found of the range of union influence on the legally prescribed councils. The presentations hardly reflect the reality in ignoring the myriad adjustments made on the shop floor through these employee representatives to improve the employee's rights and protection and the competitive position of the individual enterprises. Concern by the writers about political strikes is by and large an anachronism.

Individual chapters do report union innovations in policy and practices to adapt the operations to the new job environments, employee qualities, training and aspirations. But they are not considered in the ultimate evaluation. While still limited in number, their future growth, modification and greater effectiveness will reflect the dynamic nature of the union movement and mock the pessimism permeating these discussions.

It would have been helpful for the sake of balance to have had a report on management's many techniques to bypass the conditions about which it complains, including subcontracting, outsourcing, part-time and temporary employees and relocations of operations. The text offers little information on recent developments in which automatic cost of living adjustments have been virtually eliminated and actual wage increases have been hardly sufficient to maintain real earnings. Social benefits have been somewhat pruned and real unit labor costs fallen in a number of countries.

In view of the preeminence assigned to the issue of centralization and decentralization in negotiations and standards and extended a prior philosophizing on this subject, sad it is that no writer addressed himself fully to the subject. Only the Danish chapter introduces several complications likely to ensue from decentralization. The author observes that the Danish Employers Federation(DA)'s «staff is not geared or trained to master such functions and an extremely decentralized wage system also makes it difficult and delicate to implement the important Article 23 of the DA's constitution", which requires individual members not to «enter into collective agreements of normal or general contents without prior agreements of the DA General Council». It has already been noted that the Swedish SAF has begun to have second thoughts on the proposals for decentralization. The Dutch have not successfully implemented this principle. Glib formulae and catchwords, even if offered by employers, hardly assure us of workable solutions. This lesson is also apparent in the experience of the American automobile and steel industries. It is difficult to achieve a workable alignment affording the maximum amount of decentralization while maintaining overall uniformity of standards.

The book offers scant information about the preparedness of the individual managements and associations to deal with the vast range of problems arising in this new era. Again, the Danish author throws light on this aspect of the experience. He concludes that «the DA is facing a challenge if it is to take on board its president's and leading member federations' proposals about the future development of private enterprises and their conditions as regards their industrial relations systems».

Since one critical issue raised in this volume stems from the ideological outcries against union intrusion into management decision making, it would have been appropriate for the writers and editor to have evaluated the experience with this practice. In Germany, the country with the longest experience, public statements by political and industrial figures and academic studies generally have been laudatory of the arrangements. Similarly, as to employee investment funds, the opposition overlooks possible benefits, including the creation of a new source 
of investment capital and the moderating effects on union wage demands, particularly during periods of high economic activity. The observe of these positive consequences are the actual conflict and tension produced by the employers' moves to frustrate these developments.

\section{Country Reports}

Not only is there a discrepancy between the general conclusions of this volume and evidence in the separate chapters, but the précis for these contributions by the American author and in the final chapter do not square with the facts. Some of these discrepancies will be noted. In France employers and unions now enjoy a charter of rights which significantly broadened their rights and benefits. A new central organization has appeared consisting of independent unions for nonmanual employees, Confederation of Free Trade Unions (CSL); it is however not recognized as a rationally representative union. The central employers' federation (CNPF) acquired the right to negotiate agreements with unions and the government and has concluded such instruments on a number of subjects. "Union sections» approved by law for establishments now complement works councils and have multiplied impressively, opening the way for negotiating establishment collective wage agreements. Under the benevolent government of a Socialist administration, moderation of behavior has become typical in industrial relations.

Sweden in recent years witnessed the growth of three white collar and professional union centers as well as the LO. After a period of sparring, closer rapport exists among these groups. In 1985 all agreements followed the wage pattern set by the LO. Prolonged negotiations led to a detailed agreement on the administration of the Codetermination Law of 1977. One of the oddities in the chapter is the author's efforts to devise a Swedish version of the older Michels Iron Law on Oligarchy. It appears to be a forced effort in the light of the tension among the union centers and the many union programs for polling their membership's opinions and their extensive educational efforts.

Norway with a socialist government in the seventies and a nonsocialist one in the eighties also reports the formation of a new white collar and public employee organization, Confederation of Vocational Organizations (YS), the Federation of Norwegian Professional Associations (AF) and a continued high level of union influence. After a period of contention all branches in 1984 followed the wage patterns set by the LO metal workers contract. However, the truculent public employees engaged in a strike resolved by a governmentally forced arbitration arrangement. Unions in this country sidetracked experiments for autonomous work groups and through legislation secured a modified system of labor representation on corporate boards and an advanced system of improving the work environment in which union officials gained broad powers.

An abstract pattern of organizational development is foisted on the Italian trade union and industrial relations scenes by the author of this chapter. It omits a significant element, the independent unions. The author posits that «the traditional basis and methods of unionism are under question". In speculating on the shape of the future industrial relations system, he offers a system in which unions would achieve their influence through lobbying, company level bargaining and organizational participation. His purpose is to eliminate centralized bargaining and achieve collaborative relations between employees and management at the local level. Despite the many insightful remarks, the chapter hardly qualifies as a well rounded critique, derived from an understanding of the total array of forces shaping the Italian trade union and industrial relations systems.

The four other country reviews relate to countries in which conservative governments replaced Labor or Social Democratic ones. Three are coalitions and one is governed by a cabinet without an assured majority. They range from pursuing an aggressive anti-union policy 
in Great Britain to those determined to avoid confrontations with unions. The British government has sponsored legislative reforms calling for membership votes on strikes, officer elections by ballots, closed shops, check-offs and political funds and curbs on their rights to engage in secondary boycotts. Generally, the membership has in these votes supported unions to maintain their practices. But the government successfully defeated strikes in public industries (mines and railroads). Employers in the private sector have avoided open confrontations with the major exception of the publishing and printing industry. The alarmist tone of the chapter concerning the leftist influence appears grounded in a lack of recognition of the moderate disposition of the membership and a vast majority of the leadership and a fear of the professional leftist. But, of course, the dire circumstances of the British working population provide a base for much discontent and protest. Moderate trade unions such as The Electrical, Electronic, Telecommunications and Plumbing unions are encouraging new patterns in collective bargaining which favor one-union, no-strike agreements. The author acknowledges the pressure from the backbenders in the Conservative Party on the leaders' attitudes to moderate their attitudes, feeling that «there was much to be gained by closer contact with the TUC».

The analysis of the German situation reflects a terror stricken response to the fear of the influence of radicals on the trade union movement. This ensnares the author to overstate his concerns. He warns that programs inspired by them would have a "negative influence on industrial peace and economic situations of the Federal Republic Germany». To ward off this threat he urges «employers and trade associations...not...to compromise on fundamental issues and (to take) on board the possibility of conflict». He fails to consider the moderate nature of the national trade union movement and its inherent sensitivity to this question. Under the conservative government no initiatives have been taken against trade unions until the current effort to limit unemployment benefits for people laid off by reason of third party strikes. The country has been proud of its postwar industrial relations. Strikes have generally focused on issues arising in negotiations. In recent years, the primary demand has been a reduction in working hours. The major exceptions were demonstrations on political issues relating to the maintenance of the codetermination system in the iron and steel industry (1981) and the other concerning limits on the payment of unemployment benefits (1986).

Despite the sweeping reformist rhetoric of parts of the trade union movement in the Netherlands, it has been known for its pragmatism. In recent years, with the weakening of the economy and the sharp rise in unemployment, its attention has been focused on the reduction of working hours. In 1983, it traded off a pending cost of living adjustment for a 38-hour week. In current negotiations it is pressing for further reductions, youth employment schemes and retraining for the unemployed. Public employees struck for twelve weeks in response to the government's attempt to reduce wages and lay off employees as prescribed by its austerity budget. The major recent change in the industrial relations scene has been the formation by employers of a central organization to coordinate their efforts to resist union demands and to influence the government's economic policy. Despite the divisions within the movement into three centers, they are at times able to present a single platform. Underlying the many forces operating in this country is the long term experience with central direction of economic policy and collective bargaining which persists despite the recurrent pledges to promote decentralized settlements.

In Denmark the union movement has grown in membership in part because the unions administer the unemployment benefit system and the increased penetration of white collar and public employees. A new union center for white collar and public employees has made great strides (FTF). It, like the other national movements, now focuses its attention on techniques for stimulating employment. Having failed to secure national publicly financed employee investment funds, the unions designed an employee financed fund supplemented by investments by the business and finance communities. It is the one country where the political climate is 
strongly impacted by leftist influences through two minor parties which are left of the major Social Democratic Party. This shift is attributed to the large young population and the pressures for solving the unemployment problem.

\section{The Issues}

The "Summary Conclusion» itself and several of the contributors focus on the alleged decline in union membership and influence. Quite apart from the inaccuracy of this conclusion, they agree that "we have not entered into a post-trade union society", the threshold of which "has already been crossed in the USA». But the internal evidence in the individual chapters contradicts this premise and affirms the essential vitality of the movement, though it is taking new forms. Paradoxically, they assume that recovery of union power is feasible. For them the remedy is quite evident. It is acquiescence in the employer oriented policy system. Unions should scrap their «notions of industrial democracy» and concentrate on traditional concerns in collective bargaining, namely, wages, hours and working conditions. They should avoid increases in labor costs which generate inflation and increase unemployment. "This requires that under conditions of advanced technology and volatile economic circumstances the role of the unions must be reconciled with decentralization, adaptation, flexibility, mobility, involvements and low-cost conflict resolution which are essential means to this achievement of the more efficient use of resources and improvement in the quality of working life.»

Ignored are the forces, conditions, aspirations which generated in the great mass of people wider horizons which inspired the new demands. Unrecognized also is the underlying state of frustration and the deterioration of morale resulting from high unemployment. Absent is the sensitivity to the miseries in a society which neglects these aspirations and tolerates social maladies and economic abuses and failures. They are the sparks that feed the flames of economic and social conflagration and revolt. Homo Economicus is not the whole man.

Perhaps the original guidelines for the writers were too limited in scope for a satisfactory evaluation of the national systems. No doubt, the contributors were well acquainted with the history of the trade union movement, its episodic development and the underlying vigor and resilience. Acquiesence in management policies suggested in this book is essentially foreign to its nature and raison d'être.

Pleas for the restoration of the past and insistence on a unilateralist philosophy offer no constructive course for restructuring the economies nor implanting a strong determination to meet common problems or face new challenges. A positive direction would find management ready to recognize the new expectations, admit the existence of troublesome conditions and work jointly with the unions for problem resolution. Management must acknowledge that the premises for the future must be different from those on which the past comity had been built. The Swedes know better than most people that joint consultation and accomodation, not onesided reservations for negotiations and confrontation, provide the surest base for building the future. The Saltsjobaden agreement of 1938 resolved the fundamental issues of an earlier part of the century. A new agreement is in order to overcome present differences. It therefore behooves the reviewer to propose that the Swedish Employers Federation invite the three national union centers to join in the sponsorship of a new volume of contributors to develop a bipartisan set of premises for the ultimate negotiations of the new agreement.

Solomon BARKIN

University of Massachusetts/Amherst 